\title{
PKM Kelompok PKK Kecamatan Tikala Manado Tentang Pemanfaatan Pupuk Hijau Untuk Meningkatkan Produksi Tanaman Hias dan Sayuran Sebagai Peluang Bisnis Bagi Ibu-Ibu PKK
}

\author{
Susan Marlein Mambu ${ }^{{ }^{*}}$, Marina Flora Oktavine Singkoh ${ }^{1}$ \\ 1Jurusan Biologi Fakultas Matematika dan IlmuPengetahuanAlam \\ Universitas Sam Ratulangi \\ *Penulis Korespondensi, Susan Marlein Mambu Jurusan Biologi FMIPA Universitas Sam Ratulangi \\ Manado 95115. Email: susan.mambu@unsrat.ac.id
}

\begin{abstract}
ABSTRAK
Tanaman hias tidak lagi dipajang di luar rumah, tapi juga di dalam rumah. Peluang bisnis ini bukan hanya untuk kalangan pengusaha tetapi juga bagi ibu rumah tangga yang memiliki keahlian merawat tanaman. Selain tanaman hias, para ibu rumah tangga juga bisa menjual tanaman hias dan sayuran yang bisa digunakan untuk keperluan dapur. Harga tanaman hias yang fluktuatif, harus disesuaikan dengan kondisi pasar, sehingga diperlukan perencanaan manajemen keuangan yang baik. Salah satu kendala selain ketersediaan bibit, yaitu harga pupuk yang mahal, membuat biaya penjualan menjadi tinggi, sehingga peluang bisnis ini menjadi kurang diminati. Penggunaan pupuk organik dalam hal ini pupuk hijau yang berasal dari sisa-sisa panen tanaman dapat menjadi alternatif untuk menekan harga penggunaan pupuk buatan. Bahan dari tanaman ini dapat dibenamkan pada waktu masih hijau atau segera setelah dikomposkan. Program kemitraan ini bertujuan untuk memanfaatkan sisa-sisa tanaman panen untuk dijadikan pupuk hijau yang berguna untuk meningkatkan kandungan bahan organik dan unsur hara dalam tanah, sehingga terjadi perbaikan sifat fisik, kimia dan biologi tanah, yang akhirnya berdampak pada peningkatan produktivitas tanah dan meningkatkan pertumbuhan dan produksi tanaman khususnya tanaman hias dan sayuran sebagai peluang bisnis yang bisa menjadi alternatif penghasilan tambahan bagi para ibu-ibu PKK di Kecamatan Tikala Manado. Metode pelaksanaan kegiatan yaitu metode berbasis kelompok yang dilakukan secara komprehensif meliputi penyuluhan, demonstrasi serta tutorial untuk meningkatkan pengetahuan tentang pembuatan pupuk hijau, dan meningkatkan keterampilan menghasilkan produk. Kegiatan tim PKM dilakukan secara terukur disertai proses monitoring evaluasi untuk mengukur ketercapaian target. Hasil praktek menunjukkan bahwa kriteria tertinggi pada aspek ke 3 (motivasi peserta menindaklanjuti semua petunjuk sesuai pelatihan ) dengan kriteria sangat baik (25 peserta), sedangkan kriteria terendah pada aspek ke 5 (kemampuan peserta bekerjasama dalam tim) dengan kriteria kurang ( 2 peserta).
\end{abstract}

Kata Kunci: Pupuk hijau; Ibu PKK; Produksi; Tanaman hias; Sayuran

\section{PENDAHULUAN}

Latar Belakang

Analisis Situasi

A. Kondisi Mitra

Diakui selama ini ada anggapan bahwa kualitas perempuan dalam pembangunan masih sangat rendah, terutama di kalangan ibu rumah tangga, yang menyebabkan peran kaum perempuan tertinggal dalam segala hal. Untuk mengatasinya diperlukan upaya dan strategi mengintegrasikan gender ke dalam arus pembangunan dengan cara menempatkan perempuan sebagai subjek pembangunan dan menghilangkan faktor kendala yang dihadapi perempuan dalam pembangunan. Dreze dan Sen (1995) mengatakan bahwa pada waktu wanita menjadi kaum terdidik, mempunyai hak-hak kepemilikan, dan bebas untuk bekerja di luar rumah serta mempunyai pendapatan mandiri, inilah tanda kesejahteraan rumah tangga meningkat.

Kelompok ibu-ibu PKK di Kelurahan Paal 4 Kecamatan Tikala Kota Manado 
merupakan kelompok wanita yang sebagian besar anggotanya adalah ibu rumah tangga. Secara positif, waktu luang disela-sela mengurus keluarga dapat dimanfaatkan oleh para ibu rumah tangga untuk meningkatkan perekonomian keluarga. Namun demikian, diperlukan peningkatan kompetensi dari kelompok ibu rumah tangga untuk menghasilkan produk bahkan bagaimana memasarkannya. Dewasa ini usaha tanaman hias dan sayuran sudah sangat popular, terutama di daerah perkotaan, namun harga pupuk yang tinggi menjadi salah satu kendala bagi bisnis ini. Manado merupakan daerah yang kaya akan keanekaragaman hayati yang menyediakan sumber daya yang sangat besar untuk dimanfaatkan.

Penggunaan kembali limbah pertanian sebagai pupuk organik dapat meningkatkan populasi dan aktivitas mikroba tanah yang memegang peranan penting dalam dekomposisi limbah organik menjadi bahan organik dalam tanah sehingga dapat memperbaiki struktur tanah dan menambah penyediaan hara bagi tanaman (Hasanah et al., 2014). Penggunaan limbah pertanian sebagai pupuk organik sudah dikenal petani dari dulu, namun petani mulai meninggalkannya dan kemudian beralih pada pemakaian pupuk anorganik karena penggunaannya memberikan efek yang begitu nyata daripada pupuk organik. Kenyataanya, penggunaan pupuk anorganik secara terusmenerus dapat menjadikan tanah semakin rendah bahan organik sehingga penggunaan pupuk anorganik perlu dikurangi (Khoirunnisa et al., 2016; Nurhayati et al., 2011). Pupuk organik mempunyai peranan penting sebagai bahan pemicu kesuburan tanah (Magdalena et al., 2013). Pemberian pupuk organik kedalam tanah sudah mampu meningkatkan kemampuan tanah mengikat air, meningkatkan ketersediaaan hara di tanah, serta meningkatkan jumlah dan aktivitas mikroba dalam tanah (Musnamar, 2005).

Pemanfaatan sisa-sisa tanaman hasil panen belum banyak diperhatikan kegunaannya. Pemanfaatan bahan baku lokal akan sangat membantu peningkatan bahan baku tersebut, sehingga secara tidak langsung akan ikut meningkatkan kemajuan perekonomian daerah. Pemanfaatan, Produksi dan penjualan pupuk hijau ke pasaran merupakan salah satu usaha ekonomi kreatif yang unik dengan memanfaatkan bahan baku sisa-sisa tanaman yang selama ini tidak banyak digunakan dalam industri. Selain memberi nilai tambah pada sisa-sisa tanaman yang biasanya hanya dibuang, tetapi juga untuk mengatasi permasalahan ekonomi keluarga sehingga secara tidak langsung dapat meningkatkan ekonomi masyarakat. Sektor Usaha Mikro, Kecil, dan Menengah (UMKM) telah menyumbang sekitar 53 persen dari Produk Domestik Bruto (PDB) Indonesia pada tahun 2009 (Kementerian Perindustrian RI). Pengembangan usaha mikro kecil dan menengah keseluruhan dengan cara member dukungan positif dan nyata terhadap pengembangan sumber daya manusia, termasuk pemberdayaan wanita, dan menunjukkan keberhasilan iklim usaha yang berbasis kerakyatan.

\section{Permasalahan Mitra}

Beberapa masalah yang dihadapi kelompok mitra berdasarkan analisis situasi dapat diuraikan sebagai berikut, kurangnya pengetahuan dan informasi mengenai usahausaha skala rumah tangga bagi ibu rumah tangga, minimnya pemahaman produktivitas pada kelompok wanita sebagai ibu rumah tangga dalam membantu perekonomian keluarga; dan kurangnya kegiatan yang berorientasi pada kemandirian dalam berekonomi. Keterbatasan pengetahuan tentang kegunaan dan pembuatan pupuk hijau disebabkan karena kurangnya penerapan hasil-hasil riset yang berdampak langsung pada masyarakat termasuk dalam bidang ketahanan pangan. Kenaikan harga pupuk yang semakin hari semakin bertambah, dan pembuatan pupuk hijau sebagai alternatif dapat menjadi peluang usaha bagi para wanita dalam menunjang ekonomi keluarga. Dengan adanya pengetahuan teknik pembuatan pupuk hijau dan aplikasi pupuk hijau pada tanaman hias dan sayuran dalam usaha skala rumah tangga yang dijalankan para ibu-ibu PKK, dapat memperoleh keuntungan yang dapat meningkatkan ekonomi keluarga secara dan masyarakat secara umum.

\section{Tujuan dan Manfaat Kegiatan}

Berdasarkan hasil analisis situasi dan permasalahan yang berhasil diidentifikasi, maka tujuan kegiatan PKM ini adalah pemanfaatan sisa panen tanaman untuk dijadikan pupuk organik sebagai salah satu upaya peningkatan kompetensi para wanita dalam meningkatkan ekonomi keluarga, sehingga konsep perempuan khususnya ibu-ibu PKK harus cerdas dan mandiri dari sisi ekonomi dapat terwujud. 


\section{JPAI}

Jurnal Perempuan dan Anak Indonesia

Sesuai dengan rencana kegiatan, maka manfaat kegiatan ini berupa kontribusi transfer ilmu dan teknologi kepada kelompok ibu-ibu PKK yaitu teknik pembuatan pembuatan pupuk hijau yang dapat diaplikasikan melalui usaha tanaman hias dan sayuran dalam skala rumah tangga, selain itu luaran yang dihasilkan bagi Ibu-ibu PKK dalam kegiatan PKM ini adalah meningkatnya pengetahuan dan keterampilan pembuatan dan pengelolaan pupuk organik berbasis limbah tanamn sisa panen, yang bukan saja dapat digunakan untuk lahan Ibu-ibu PKK tapi juga dapat menjadi peluang bisnis yang dapat menambah penghasilan dan kesejahteraan keluarga.

\section{METODE PENELITIAN}

\section{Lokasi Kegiatan}

Kegiatan awal sosialisasi PKM ini dilaksanakan di Kantor Camat Tikala, dan penyuluhan serta pelatihan dilaksanakan di rumah Ketua Tim Penggerak PKK Kelurahan Banjer Kecamatan Tikala.

\section{Metode yang digunakan :}

Kegiatan pengabdian ini dilaksanakan dengan metode ceramah/penyuluhan, tutorial, demonstrasi pembuatan pupuk hijau, dan diskusi yang dilakukan di lokasi mitra. Kegiatan ceramah meliputi pengenalan jenis-jenis pupuk hijau, cara pembuatan dan pemakaian pupuk hijau bagi tanaman hias dan sayuran.

Tahapan kegiatan pengabdian ini adalah sebagai berikut:

1. Tahap 1 (Metode Ceramah/Penyuluhan):

Peserta diberikan motivasi, pengetahuan dan informasi menegenai cara memanfaatkan bahan baku local sisa-sisa tanaman yang dapat digunakan untuk peningkatan kompetensi sebagai wanita dalam rangka untuk meningkatkan ekonomi keluarga dengan usaha skala rumah tangga.

2. Tahap 2 (Metode Tutorial dan Demonstrasi):

Peserta diberikan materi konsep dan teknik pembuatan pupuk hijau dari sisasisa tanaman untuk skala rumah tangga. Pada kegiatan ini juga akan diberikan materi tentang cara mengaplikasikan berbagai pupuk hijau bagi tanaman hias dan sayuran, serta teknik melakukan pemasaran terhadap produk yang dihasilkan. Diharapkan mitra dapat melakukan teknik pembuatan pupuk hijau dari sisa-sisa tanaman.

Cara pembuatan meliputi:

1. Pemilihan jenis pupuk hijau.

Sisa-sisa tanaman ada berbagai jenis, sehingga dibutuhkan pengetahuan untuk memilih jenisnya. Antara lain jenisnya mudah terurai dan memiliki kandungan hara yang tinggi terutama unsur $\mathrm{N}$ yang terdapat pada jenis tanaman legume seperti kacang-kacangan ataupun jenis rumput tertentu.

2. Pembuatan pupuk hijau.

Setelah menentukan jenis tanaman, kemudian dilakukan pencacahan dengan alat cacah, selanjutnya dicampur dengan tanah pada wadah tertutup. Umumnya kompos akan matang dalam waktu kurang lebih 1 bulan, tergantung dari jenis tanaman yang digunakan. Kompos diisi kedalam polybag dan siap ditambahkan dengan tanah, ataupun dibenamkan ke dalam tanah jika akan menanam di lahan (Mambu, et al., 2018).

3. Tahap 3 (Metode Diskusi):

Peserta pelatihan diberikan kesempatan untuk bertanya atau mendiskusikan permasalahan yang berkaitan dengan teknik pembuatan pembuatan pupuk hijau dari sisa-sisa tanaman untuk skala rumah tangga, dan bagaimana cara mengembangkan usaha tanaman hias dan sayuran.

\section{HASIL DAN PEMBAHASAN}

\section{Hasil Pelaksanaan Kegiatan PKM}

Berdasarkan hasil penyuluhan, wawancara, tanya jawab dan pengamatan langsung selama kegiatan penyuluhan dan pelatihan berlangsung, kegiatan PKM ini memberikan hasil sebagai berikut:

\section{Hasil Penyuluhan}

a. Meningkatnya pengetahuan dan pemahaman Ibu-ibu PKK tentang limbah hasil panen tanaman yang bisa dijadikan pupuk organik. 
Jurnal Perempuan dan Anak Indonesia

b. Meningkatnya pengetahuan Ibu-ibu PKK dalam pembuatan pupuk organik berbahan dasar limbah sisa panen tanaman.

Dari penyuluhan ini, banyak pertanyaan yang muncul dari peserta, karena banyak peserta yang belum tahu apa itu pupuk organik serta penggunaannya, sehingga dilanjutkan pada tahap pelatihan.

\section{Hasil Pelatihan}

a. Meningkatnya keterampilan Ibu-ibu PKK dalam pembuatan pupuk organik berbahan dasar limbah sisa panen tanaman.

b. Meningkatnya keterampilan Ibu-ibu PKK dalam mengelola dan menggunakan pupuk organik untuk tanaman hias dan sayuran.

Kegiatan penyuluhan dan praktek pembuatan pupuk organik dapat dilihat pada gambar 1 .



Gambar 2. Penyuluhan Kegunaan dan Pembuatan Pupuk Organik

Materi yang disajikan pada kegiatan praktek ini meliputi cara pemilihan bahan sisa panen tanaman, cara membuat pupuk organik, dan aplikasi pupuk organik di media atau lahan tanam. Metode yang digunakan yaitu memperagakan cara-cara dan tahapan pembuatan pupuk organik limbah tanaman yang dapat dilihat pada

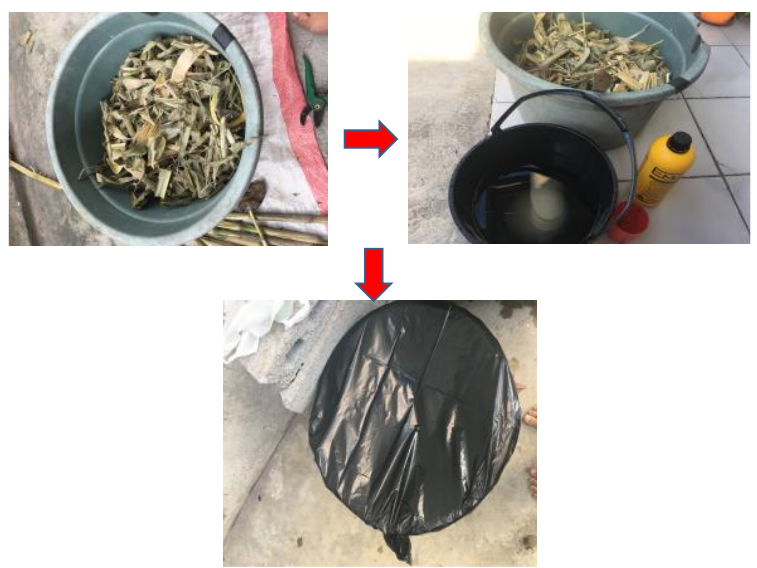

Gambar 3. Tahapan Pembuatan dan Dekomposisi Pupuk Hijau

\section{Hasil Evaluasi}

Setelah selesai pelatihan dan praktek, maka kemampuan peserta dalam memahami materi pelatihan dapat diukur melalui pengisian lembar evaluasi topik pelatihan. Oleh sebab itu setiap peserta mengisi lembar evaluasi pelatihan sesuai dengan kemampuan mereka. Ada 5 aspek yang dinilai untuk peserta sesuai dengan 5 kriteria dengan selang nilai $1-5$ yaitu $1=$ sangat kurang, $2=$ kurang, $3=$ sedang, $4=$ baik, dan $5=$ sangat baik.

Hasil pemeriksaan terhadap pengisian evaluasi topik pelatihan dari peserta menunjukkan bahwa kesesuaian materi pelatiha dengan kebutuhan peserta sangat tinggi, ternyata dari 25 orang, 22 orang (sangat baik), 3 orang (baik), dan untuk kategori sedang, kurang dan sangat kurang tidak ada. Untuk motivasi peserta dan pemahaman materi memiliki nilai yang sama yaitu, yang memiliki kriteria sangat baik ada 21 orang, baik (3 orang), sedang (1 orang), kurang dan sangat kurang tidak ada. Untuk aspek kemampuan peserta terhadap praktek yang dilakukan, setelah diukur hasilnya memperlihatkan bahwa dari 25 orang yang mengikuti praktek, ternyata ada 18 orang (sangat baik), 5 orang (baik), 2 orang (sedang), dan yang kurang, serta sangat kurang tidak ada. Dari hasil analisis juga memperlihatkan bahwa kemampuan peserta bekerjasama dalam tim, yang memiliki kriteria sangat baik (17 orang), baik (3 orang), sedang ( 3 orang), kurang ( 2 orang), sedangkan sangat kurang tidak ada. Hasil evaluasi mengambarkan bahwa masih diperlukan pelatihan lebih lanjut untuk meningkatkan keterampilan dan kerjasama tim diantara ibu-ibu 
JPAI

Jurnal Perempuan dan Anak Indonesia

PKK.Nilai keseluruhan kriteria evaluasi topik belajar disajikan pada Tabel 1 .

Tabel 1. Hasil Rekapan Evaluasi Topik Pelatihan

\begin{tabular}{|c|c|c|c|c|c|}
\hline \multirow[b]{2}{*}{$\begin{array}{l}\frac{y}{0} \\
\frac{0}{2}\end{array}$} & \multicolumn{5}{|c|}{ Total Kriteria } \\
\hline & $\begin{array}{c}\text { Sangat } \\
\text { Kurang } \\
\text { (1) }\end{array}$ & $\begin{array}{c}\text { Kurang } \\
\text { (2) }\end{array}$ & $\begin{array}{c}\text { Sedang } \\
\text { (3) }\end{array}$ & $\begin{array}{c}\text { Baik } \\
\text { (4) }\end{array}$ & $\begin{array}{c}\text { Sangat } \\
\text { Baik } \\
(5)\end{array}$ \\
\hline A & 0 & 0 & 1 & 3 & 21 \\
\hline $\mathrm{B}$ & 0 & 0 & 1 & 3 & 21 \\
\hline $\mathrm{C}$ & 0 & 0 & 0 & 3 & 22 \\
\hline $\mathrm{D}$ & 0 & 0 & 2 & 5 & 18 \\
\hline$E$ & 0 & 2 & 3 & 3 & 17 \\
\hline
\end{tabular}

Dimana:
A. Motivasi peserta
B. Pemahaman materi
C. Kesesuaian materi pelatihan dengan kebutuhan peserta
D. Kemampuan peserta mempraktekkan materi pelatihan
E. Kemampuan peserta bekerjasama dalam tim

\section{KESIMPULAN DAN SARAN Kesimpulan}

Kegiatan PKM ini telah meningkatkan pemahaman, pengetahuan dan keterampilan Ibuibu PKK mengenai jenis-jenis limbah hasil panen tanaman yang bisa digunakan kembali sebagai pupuk organik, cara pembuatan dan penggunaan pupuk organik berbasis limbah sisa panen pada lahan tanam Ibu-ibu PKK.

Peningkatan keterampilan memilih dan mengolah limbah sisa panen untuk dijadikan pupuk organik dapat diamati langsung pada saat praktek dan monitoring yang dilakukan di lapangan, terlihat jelas bahwa Ibu-ibu PKK telah mengerti proses pengolahan dan penggunaan pupuk organik olahan sendiri berbasis limbah tanaman sisa panen. Pupuk organik inipun telah diaplikasikan pada lahan tanam PKK Kecamatan Tikala dan di rumah para Ibu-ibu PKK yang telah mengikuti program PKM ini.

\section{Saran}

Mengingat besarnya manfaat kegiatan PKM ini, disarankan untuk tetap melakukan pendampingan, monitoring secara berkala dan evaluasi kinerja yang berfokus pada komersialnya produk pupuk organik hasil olahan Ibu-ibu PKK Kecamatan Tikala, untuk membantu perekonomian keluarga.

\section{UCAPAN TERIMAKASIH}

Pada kesempatan ini tim penulis mengucapkan terima kasih kepada Pimpinan Universitas Sam Ratulangi Manado dan Pimpinan LPPM Unsrat Manado yang telah mendanai kegiatan PKM ini melalui dana PNBP Unsrat tahun anggaran 2019. Ucapan terima kasih juga disampaikan kepada Ketua Tim Penggerak PKK Kecamatan Tikala dan seluruh pengurus terutama kepada Ibu-ibu PKK Kelurahan Banjer yang telah berpartisipasi aktif dalam mengikuti kegiatan PKM ini.

\section{DAFTAR PUSTAKA}

Dreze, Jean dan Sen, Amartya. 1999. The Amartya Sen and Jean Drèze Omnibus:(comprising) Poverty and Famines;Hunger and Public Action; India: Economic Development and Social Opportunity. Oxford University Press.

Hasanah, U., Simorangkir, M., Masmur, I., Durdan, S., dan Meliaty, S. E. 2014. Pemanfaatan dan Pengelolaan Pupuk Organik dari Limbah Tanaman Jagung dan Kulit Coklat. J. Pengabdian KepadaMasyarakat.20(75): 100 - 106.

Khoirunnisa, A., Bambang, G., dan Titin, S. 2016. Pengaruh Pupuk Hijau Crotalaria mucronata dan Crotalaria juncea PADA Pertumbuhan dan Hasil Tanaman Kedelai (Glycine max L.). J. Produksi Tanaman. 8 (4): 602-610.

Mambu, S., Sugihara, S., Kawame, T., Nishigaki, T., Toyota, K., Miyamaru, N., Tanaka, H., dan Kanekatsu, M. 2018. Effect of Green Manure Application on Soil Enzyme Activity and Nutrient Dynamics in a Sugarcane Field of Kitadaito, Okinawa, Japan, JARQ, 54(4):315-324

Magdalena, F., Sudiarso., Titin, S. 2013. Penggunaan Pupuk Kandang dan Pupuk Hijau Crotalaria Juncea L. untuk Mengurangi Penggunaan Pupuk Anorganik pada Tanaman Jagung (Zea mays L.). J. Produksi Tanaman. 1 (2): 1-11. 
Musnamar, E. L. 2005. Pupuk Organik Padat: Pembuatan dan Aplikasi. Jakarta: Penebar Swadaya.

Nurhayati., Jamil L., dan Rizqi S. A. 2011. Potensi Limbah Pertanian Sebagai Pupuk Organik Lokal Di Lahan Kering Dataran Rendah Iklim Basah. Jurnal Iptek Tanaman Pangan. 6 (2): 193 - 202.

Rahardian, T.S., Sumarni, T., dan Suryanto, A. 2017. Pemanfaatan Pupuk Hijau Paitan (Tithonia diversifolia) dan Krinyu (Chromolaena odorata) Dalam Peningkatan Hasil Tanaman Brokoli (Brassica oleracea), Planttropica Journal of Agriculture Science, 2(2):108-116 